\title{
Dynamics of bacterial carbon metabolism at the entrance of a tropical eutrophic bay influenced by tidal oscillation
}

\author{
Mariana Guenther ${ }^{1,4, *}$, Rodolfo Paranhos ${ }^{1}$, Carlos Eduardo Rezende ${ }^{2}$, \\ Eliane Gonzalez-Rodriguez ${ }^{3}$, Jean Louis Valentin ${ }^{1}$ \\ ${ }^{1}$ Departamento de Biologia Marinha, Instituto de Biologia, Universidade Federal do Rio de Janeiro, Rio de Janeiro, \\ RJ-CEP 21949-900, Brazil \\ ${ }^{2}$ Laboratório de Ciências Ambientais, Centro de Biociências e Biotecnologia, Universidade Estadual do Norte Fluminense, \\ Campos dos Goytacazes, RJ-CEP 28013-602, Brazil \\ ${ }^{3}$ Departamento de Oceanografia, Instituto de Estudos do Mar Almirante Paulo Moreira, Comando da Marinha, \\ Arraial do Cabo, RJ-CEP 28930-000, Brazil
}

${ }^{4}$ Present address: Departamento de Oceanografia, Universidade Federal de Pernambuco, Recife, PE-CEP: 50670-901, Brazil

\begin{abstract}
Bacterial metabolic rates were assessed at the entrance to Guanabara Bay, SE Brazil, during the summer (i.e. wet) season, in order to evaluate short-term effects of tidal oscillation on the magnitude of carbon flow through the bacterioplankton. Bacterial production (BP), respiration (BR) and abundance, phytoplankton production and biomass, particulate and dissolved organic matter (POM and DOM) concentrations and elemental composition, nutrient concentrations and hydrological profiles were estimated at a fixed station during 3 consecutive days with intervals of $3 \mathrm{~h}$, in surface and bottom $(20 \mathrm{~m}$ ) layers. The study period covered the end of the spring tide and the beginning of the neap tide. Bacterial metabolic rates were highly variable, and a small fraction of the dissolved organic carbon (DOC) pool was used by bacterioplankton (DOC turnover: 23 to $71 \mathrm{~d}$ ). The input of allochthonous DOC, inferred from DOM elemental composition (C:N:P $\mathrm{P}_{\text {surface }} \sim 150: 9: 1 ; \mathrm{C}: \mathrm{N}: \mathrm{P}_{\text {bottom }}$ 245:6:1), and temperature were the main controlling factors of bacterial carbon metabolism. Although the magnitude of carbon flow through the bacterioplankton was highly variable, there were nevertheless consistent differences between layers. At the surface, the particulate organic carbon (POC) production $\left(\sim 14.3 \mu \mathrm{M} \mathrm{C} \mathrm{h}^{-1}\right)$, mainly due to phytoplankton, was higher than $\mathrm{BR}$, and bacterioplankton acted equally as POC producers and DOM remineralizers (bacterial growth efficiency $\sim 52 \%)$. Near the bottom, BR was equivalent to total POC production $(\sim 0.3 \mu \mathrm{M} \mathrm{C} \mathrm{h})$ and higher than BP $\left(\sim 0.05 \mu \mathrm{M} \mathrm{C} \mathrm{h}^{-1}\right)$, and thus bacteria acted mostly as a DOM sink. This study highlights the importance of short-term variations in carbon flow through bacteria for understanding the carbon cycle of estuarine systems.
\end{abstract}

KEY WORDS: Bacterial production · Bacterial respiration · Bacterial growth efficiency · Carbon flux · Guanabara Bay · Estuary

\section{INTRODUCTION}

Heterotrophic bacterioplankton constitutes the dominant fraction of plankton biomass and is also a key compartment in carbon cycling through aquatic systems (Ducklow 2000). Besides converting dissolved organic matter (DOM) into a food source for higher trophic levels, these organisms are important inorganic carbon $\left(\mathrm{CO}_{2}\right)$ suppliers via organic matter oxidation. The magnitude of carbon flow through bacterioplankton must thus be estimated with simultaneous measurements of bacterial production (BP) and respi- 
ration (BR), which represent, respectively, the amount of carbon incorporated into bacterial biomass and that used for ATP generation and thus lost as $\mathrm{CO}_{2}$ (Jahnke \& Craven 1995, del Giorgio et al. 1997).

The sum of BP and BR provides an estimate of the total amount of organic carbon assimilated by bacteria, the bacterial carbon demand (BCD), as well as the proportion of carbon actually converted into bacterial biomass, the bacterial growth efficiency (BGE). The latter is a measure of the physiological state of bacterial cells, and can also be used as an indicator of the bacterioplankton role in a system: a high BGE indicates that bacteria are more important as a source of particulate organic matter, while a low BGE indicates that they act mainly as a sink of organic matter and a source of $\mathrm{CO}_{2}$ and other inorganic nutrients (del Giorgio \& Cole 1998).

Estuaries and coastal bays are complex hydrodynamic systems, under both oceanic and terrestrial
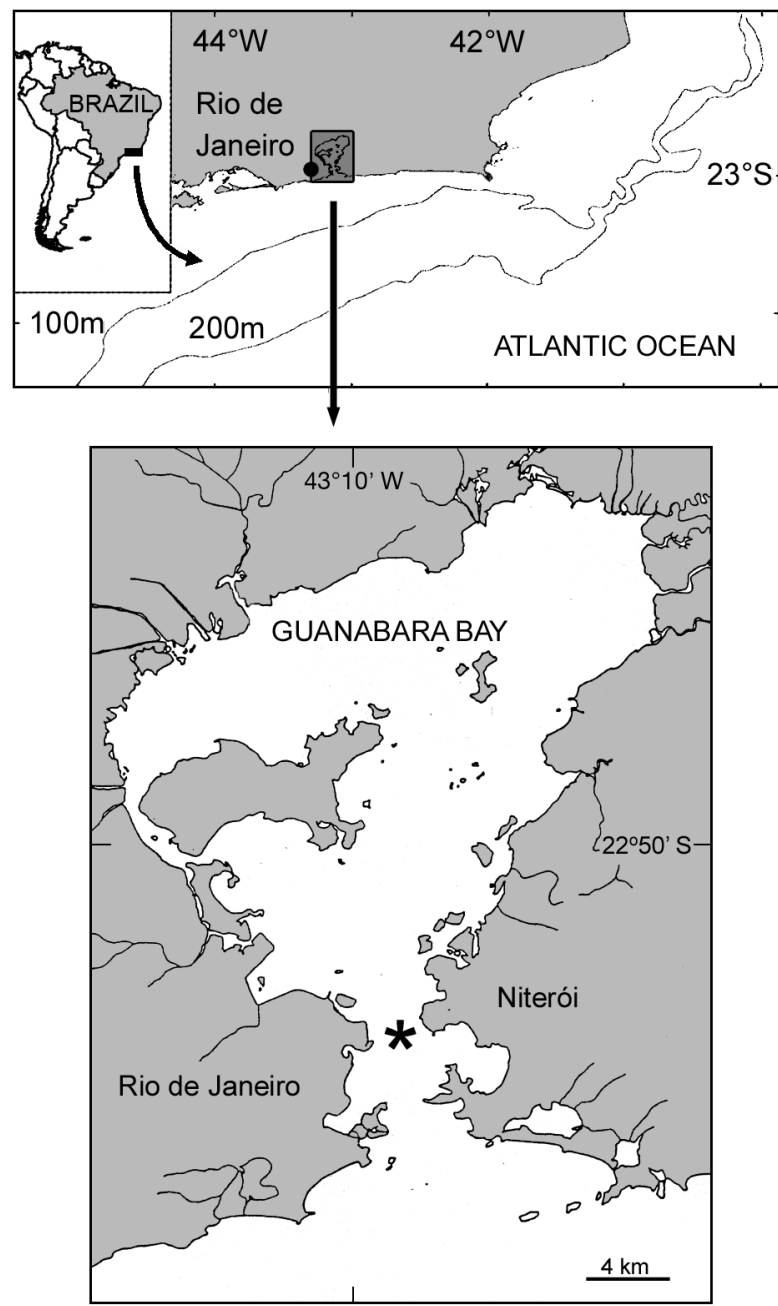

Fig. 1. Study area and fixed sampling station (*) in Guanabara Bay, Rio de Janeiro state, Brazil influence, driven by riverine input on the one hand and tidal oscillation on the other (Dyer 1997). Moreover, these systems are important sources of organic matter and energy for the adjacent oceanic areas (McLusky 1989). Guanabara Bay, SE Brazil (22 $\left.50^{\prime} \mathrm{S}, 43^{\circ} 10^{\prime} \mathrm{W}\right)$, receives high loads of nutrients and organic material from riverine sources and from domestic and industrial sewage inputs. As a consequence, this system is characterized by high phytoplankton and bacterial biomass and production (Valentin et al. 1999b, Paranhos et al. 2001). Furthermore, variations in tidal amplitude result in distinct circulation patterns within the bay. During spring tide, tidal currents represent the main driving force of transport at the entrance to the bay, while, during neap tide, freshwater discharge from the inner portions of the bay becomes equally important (Bergamo 2006). We hypothesized that the hydrological variations at the entrance to Guanabara Bay would affect nutrient and organic matter distribution and, thus, bacterial metabolic rates and carbon consumption dynamics.

Studies concerning bacterial carbon metabolism using simultaneous measurements of BP and BR in tropical systems are scarce. Furthermore, most studies developed in temperate areas used broad spatial scales and low temporal resolution (e.g. Lemée et al. 2002, Reinthaler \& Herndl 2005, del Giorgio et al. 2006). The aim of the present study was to use a shortterm, highly resolved temporal survey to evaluate the effects of tidal oscillation on the magnitude of carbon flow through bacterioplankton at the transition area between the bay and the coastal ocean.

\section{MATERIALS AND METHODS}

Study area. Guanabara Bay (Fig. 1), in Rio de Janeiro state, Brazil $\left(22^{\circ} 41^{\prime}\right.$ to $22^{\circ} 56^{\prime} \mathrm{S}$ and $43^{\circ} 02^{\prime}$ to $43^{\circ} 18^{\prime} \mathrm{W}$ ), is $36 \mathrm{~km}$ long and $29 \mathrm{~km}$ wide, with a surface area of $400 \mathrm{~km}^{2}$ and a water volume of approximately $3.0 \times 10^{9} \mathrm{~m}^{3}$ (Amador 1997). This system experiences steep spatial gradients from the entrance to the inner bay, in terms of salinity (37 to 13.5 ), dissolved oxygen (DO: 15 to $0.0 \mathrm{mg} \mathrm{l}^{-1}$ ), phosphate $\left(\mathrm{P}-\mathrm{PO}_{4}:<0.03\right.$ to $308.0 \mu \mathrm{M})$, ammonium $\left(\mathrm{N}-\mathrm{NH}_{4}:<0.03\right.$ to $\left.650 \mu \mathrm{M}\right)$, nitrate $\left(\mathrm{N}^{-\mathrm{NO}_{3}}\right.$ : 60.0 to $\left.<0.03 \mu \mathrm{M}\right)$ and chlorophyll $a$ (chl a: 4.0 to $150 \mathrm{\mu g} \mathrm{l}^{-1}$ ) (Mayr et al. 1989, Paranhos et al. 1998). Water depth varies from $25 \mathrm{~m}$ at the entrance to $<1 \mathrm{~m}$ in the inner areas, and tidal current speeds vary from 80 to $150 \mathrm{~cm} \mathrm{~s}^{-1}$ at the entrance, which is only $1.5 \mathrm{~km}$ wide, to $<30 \mathrm{~cm} \mathrm{~s}^{-1}$ in the inner areas (JICA 1994). Freshwater discharge originates from 35 rivers and streams, and ranges from $40 \mathrm{~m}^{3} \mathrm{~s}^{-1}$ during the dry season (winter) to $190 \mathrm{~m}^{3} \mathrm{~s}^{-1}$ during the wet season (summer) (Kjerfve et al. 1997). 


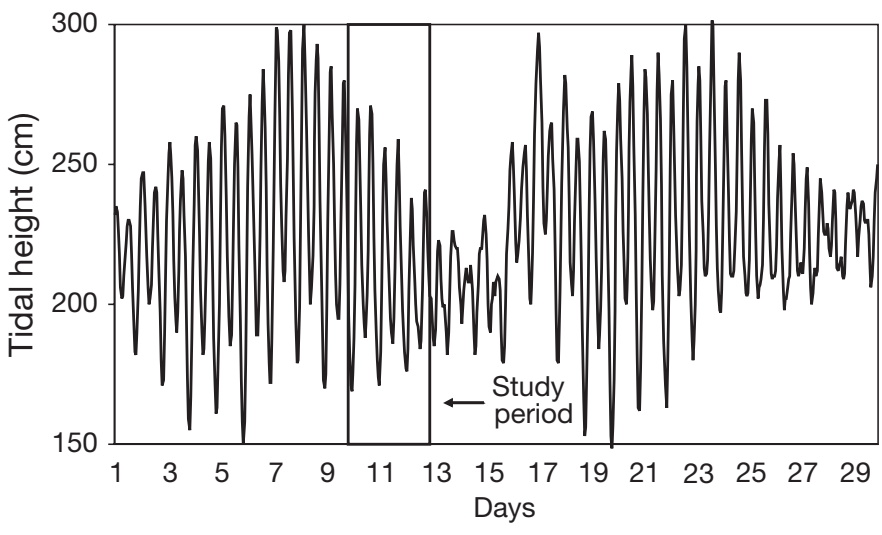

Fig. 2. Tidal height during February 2004 at the entrance to Guanabara Bay

Experimental design. A high-resolution survey, over 3 consecutive days with intervals of $3 \mathrm{~h}$, was conducted during the wet season at a fixed station $\left(22^{\circ} 54^{\prime} \mathrm{S}\right.$, $43^{\circ} 09^{\prime} \mathrm{W}$ ) located near the entrance to the Guanabara Bay's main channel (Fig. 1). The period chosen for the present study spanned from the end of spring tide to the beginning of neap tide, as indicated by the tidal oscillation record provided by the Brazilian Navy Hydrography and Navigation Department (DHN; Fig. 2). Water samples were collected with Niskin bottles (10 l) at the surface and near the bottom $(20 \mathrm{~m})$ for DO, nutrients, dissolved and particulate organic matter (DOM and POM), chl $a$ and bacterial abundance (BA) analyses, and for primary production (PP), BP and BR incubation experiments. Temperature, salinity, density and irradiance profiles were simultaneously obtained using a Seabird Seacat 19 CTD system. Water-column stability was estimated from the density difference at the bottom and surface related to the average density: $\left(\sigma_{\mathrm{b}}-\sigma_{\mathrm{s}}\right) / \sigma_{\mathrm{x}}$.

Sample analyses. DO content was estimated on board using Winkler titration (Aminot \& Chaussepied 1983), and nutrient concentrations were determined in the laboratory within $12 \mathrm{~h}$ of collection, following the methods proposed by Grasshoff et al. (1983) for N$\mathrm{NO}_{2}, \mathrm{~N}-\mathrm{NO}_{3}, \mathrm{P}-\mathrm{PO}_{4}$ and silicate $\left(\mathrm{Si}-\mathrm{SiO}_{4}\right)$ and by Parsons et al. (1984) for $\mathrm{N}-\mathrm{NH}_{4}$.

DOM and POM contents were evaluated as their elemental compositions: dissolved and particulate organic carbon, nitrogen and phosphorous (DOC, POC, DON, PON, DOP and POP, respectively). Samples were filtered through pre-combusted $\left(450^{\circ} \mathrm{C}\right.$ for $\left.3 \mathrm{~h}\right) \mathrm{GF} / \mathrm{F}$ filters. Filters were stored at $8^{\circ} \mathrm{C}$, and filtrates were preserved in phosphoric acid $\left(10 \% \mathrm{H}_{3} \mathrm{PO}_{4}\right)$ and refrigerated in amber bottles on board. PON and POC were determined using a Perkins Elmer Series II CHNS/O Elemental Analyzer, and POP was determined after digestion of the filters with potassium persulphate.
DOC analyses were performed on the filtrates after further sample acidification $(2 \mathrm{~N} \mathrm{HCl})$ and sparging with ultra-pure air, by high-temperature catalytic oxidation with a TOC-5000 Shimadzu Total Carbon Analyzer. Total dissolved nitrogen (TDN) and total dissolved phosphorus (TDP) were determined after digestion of the filtrates with potassium persulphate. DON and DOP were calculated by subtraction of the sum of nitrogen inorganic forms $\left(\mathrm{N}-\mathrm{NO}_{3}, \mathrm{~N}-\mathrm{NO}_{2}\right.$ and $\left.\mathrm{N}-\mathrm{NH}_{4}\right)$ from TDN and $\mathrm{P}_{-} \mathrm{PO}_{4}$ from TDP. The reproducibility of these analyses was estimated using 3 replicates, yielding an analytical variability $<2 \%$.

Samples for chl a were filtered through $0.45 \mu \mathrm{m}$ cellulose membranes subsequently stored in cryogenic vials in liquid nitrogen on board. In the laboratory, chl a contents were determined using a Turner Designs fluorometer after $18 \mathrm{~h}$ acetone $90 \%$ extraction at $4^{\circ} \mathrm{C}$, following Parsons et al. (1984).

Bacterial abundance was determined using flow cytometry following del Giorgio et al. (1996). Water samples $(1.7 \mathrm{ml})$ were preserved in sterile $2.0 \mathrm{ml}$ screwcap tubes with $2 \%$ paraformaldehyde for $30 \mathrm{~min}$ and then stored in liquid nitrogen. In the laboratory, samples were thawed, stained with Syto 13 at $2.5 \mu \mathrm{M}$ final concentration, and run, after 15 min staining in the dark, in a CyAn ADP (Dako) flow cytometer with a laser emitting at $488 \mathrm{~nm}$. Fluorescent latex beads (1.58 $\mu \mathrm{m}$ diameter) were used for calibration (Lebaron et al. 1994).

PP was estimated using the ${ }^{14} \mathrm{C}$ uptake method (Steemann-Nielsen 1952). Samples were incubated in situ in $60 \mathrm{ml}$ polycarbonate bottles (2 light and 1 dark) with $10 \mu \mathrm{Ci} \mathrm{NaH}{ }^{14} \mathrm{CO}_{3}$. At the end of $3 \mathrm{~h}$ incubations, samples were filtered through $0.45 \mu \mathrm{m}$ cellulose membranes, which were placed in scintillation vials and stored frozen on board. In the laboratory, $1.0 \mathrm{ml}$ of $1 \mathrm{M}$ $\mathrm{HCl}$ was added, and the vials were left open for $12 \mathrm{~h}$ for removal of ${ }^{14} \mathrm{CO}_{2}$ that was not incorporated. After addition of scintillation liquid, isotopic activity was determined using a Packard Tricarb 1600 TR scintillation counter, with internal calibration and quench correction.

BP was assessed following Smith \& Azam (1992). Triplicate samples $(1.7 \mathrm{ml})$ were incubated for $1 \mathrm{~h}$ in sterile $2.0 \mathrm{ml}$ screwcap tubes with L-[4,5- $\left.{ }^{3} \mathrm{H}\right]$ leucine (Amersham TRK 510; specific activity: $171 \mathrm{Ci} \mathrm{nmol}^{-1}$ ) at a $10 \mathrm{nM}$ final concentration, based on previous saturation curves (Gonzalez et al. 2000). One tube was amended with $90 \mu \mathrm{l} 100 \%$ ice-cold trichloroacetic acid (TCA) as a killed control. The incubations were performed in separate thermal boxes, 1 for each sample depth, in order to preserve in situ temperatures. At the end of $1 \mathrm{~h}$, the incubation was stopped by addition of TCA, and the tubes were immediately frozen on board. In the laboratory, samples were processed and the iso- 
topic activity was determined in a Beckman LS6000SC scintillation counter, with internal calibration and quench correction. Bacterial carbon production was calculated using a protein/carbon conversion factor of 0.86 (Simon \& Azam 1989). Bacterial specific production rates (BSP) were calculated as the ratio of $\mathrm{BP}$ to bacterial abundance.

Samples for determination of BR were filtered through $1.2 \mu \mathrm{m}$ polycarbonate membranes and distributed into $150 \mathrm{ml}$ bottles. One of the 3 bottles, representing initial DO concentrations, was immediately fixed with Winkler reagents (manganese sulphide and alkaline iodine), while the other 2 were incubated in situ in the dark (wrapped in aluminium foil and black plastic bags) for $24 \mathrm{~h}$. After incubation, the bottles were immediately fixed with the same reagents and the oxygen concentration was determined using Winkler titration (Aminot \& Chaussepied 1983). Respiration rates were estimated using a respiration quotient (RQ) of 1.0 (Biddanda et al. 1994). Bacterial specific respiration rates (BSR) were calculated as the ratio of $\mathrm{BR}$ to bacterial abundance; $\mathrm{BCD}$ was calculated as $\mathrm{BP}+\mathrm{BR}$, DOC turnover through bacterial consumption as DOC/BCD, and BGE as BP/BCD (del Giorgio \& Cole 1998).

Data analyses. Differences within each variable at each tidal phase (high, ebb, low and flood), period (spring, transition and neap tide) and layer (surface and bottom) were tested using an analysis of variance (ANOVA) followed by Tukey's post hoc multiple-comparison test. The relationships between bacterial rates (BP, BSP, BR, BSR, BCD and BGE) and several predictor variables selected from a preliminary analysis $(\mathrm{N}$ $\mathrm{NH}_{4}, \mathrm{~N}-\mathrm{NO}_{3}, \mathrm{P}_{-} \mathrm{PO}_{4}, \mathrm{DOC}, \mathrm{DOM} \mathrm{C}: \mathrm{N}$ and C:P ratios, $\mathrm{DO}, \mathrm{T}, \mathrm{S}$ and $\mathrm{chl}$ a) were analyzed using standard (including intercept) forward stepwise multiple regression. The model was executed with a tolerance of $>0.10$, and residual statistics were computed in order to identify any extreme outliers. When one or several cases fell outside \pm 3 times the residual standard deviation, the respective cases were excluded and the analysis was run again. Data normality was tested using a Kolmogorov-Smirnov test, and a $\log (x)$ transformation was applied in cases of lack of normality. All tests were performed using STATISTICA Version 7.0 (StatSoft).

\section{RESULTS}

\section{Hydrology}

The study was divided into 3 distinct periods based on tidal amplitude and phase regularity: (I) spring tide (first day) - with regular tidal phases (ebb/flood: 6 h) and high amplitude $(1.0 \mathrm{~m})$; (II) transition between spring and neap tide (second day) - when tidal phases became less regular (ebb: 7 to $8 \mathrm{~h}$, flood: 4 to $5 \mathrm{~h}$ ) and amplitude decreased $(0.7 \mathrm{~m})$; (III) neap tide (third day) — the lowest amplitude: $0.5 \mathrm{~m}$ (Fig. 3). No differences between tidal phases (high, ebb, low and flood) were observed for the sampled variables (data not shown). However, significant variations between tidal periods (spring, transition and neap tide) and/or layers (surface and bottom) were observed for most of the variables sampled and rates measured (Tables 1 \& 2).

During spring tide (Period I), the water column was slightly thermally stratified during the first $6 \mathrm{~h}$, ranging from $20.8^{\circ} \mathrm{C}$ near the bottom to $23.3^{\circ} \mathrm{C}$ at the surface, becoming homogeneous thereafter, at around $23^{\circ} \mathrm{C}$. During the transition period (Period II), water temperature increased at the surface $\left(24\right.$ to $\left.24.5^{\circ} \mathrm{C}\right)$, reaching $25^{\circ} \mathrm{C}$ during neap tide (Period III), and decreased near the bottom $\left(20^{\circ} \mathrm{C}\right)$, forming thermal stratification (Fig. 4a). Isohalines indicated a steep decrease in salinity at the surface, from 33 at high tidal phases during spring tide (Period I) to 25.6 at low tidal phases during neap tide. Near the bottom there was only a slight increase in salinity, from 34 to 35 (Fig. 4b). The isopycnals indicate a gradual increase in water-column stability from the first $6 \mathrm{~h}$ of study: lower at the middle of Period I and higher at the end of Period III (Figs. 4c $\& 5)$.

Concentrations of nutrients, POM, chl $a$ and BA during spring tide were equivalent in both layers, except for $\mathrm{Si}_{-} \mathrm{SiO}_{4}$, which was higher at the surface (Table 1, Fig. $6 \mathrm{a}$ for $\mathrm{BA}$ ). In the transition and neap tide periods, POM, chl $a, \quad \mathrm{~N}-\mathrm{NO}_{2}$ and $\mathrm{Si}_{-}-\mathrm{SiO}_{4}$ concentrations increased at the surface, while BA and $\mathrm{N}-\mathrm{NO}_{3}$ concentrations increased near the bottom. DOM concentrations were higher at the surface, with no significant difference between tidal periods, except for surface DOC concentrations, which were higher during transition and neap tide. The C:N and C:P atomic ratios of

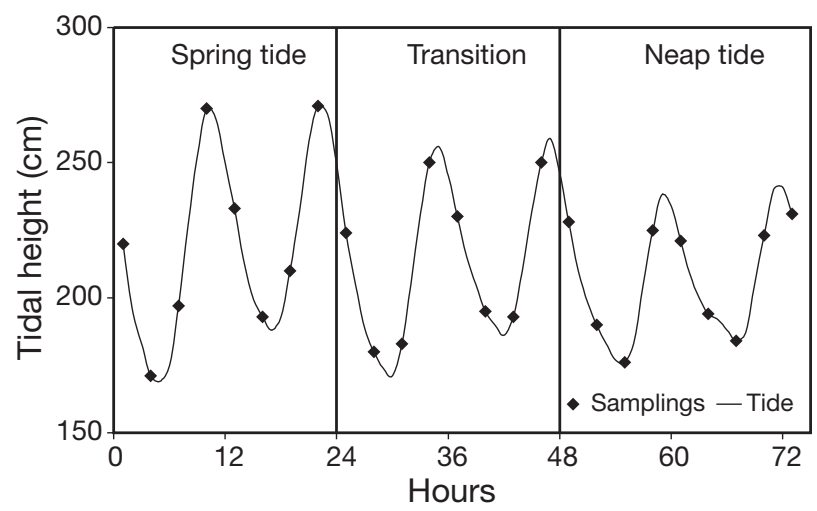

Fig. 3. Tidal height and sampling stations during the 3 periods of study at the entrance to Guanabara Bay 
DOM were higher near the bottom (average $C: N=43$ and $C: P=245$ ) than at the surface (average $C: N=17$ and $C: P=151$ ), with no significant difference between tidal periods. The POM $\mathrm{C}: \mathrm{N}$ and $\mathrm{C}: \mathrm{P}$ atomic ratios (average $\mathrm{C}: \mathrm{N}=7.6$ and $\mathrm{C}: \mathrm{P}=82$ ), $\mathrm{DO}, \mathrm{P}-\mathrm{PO}_{4}$ and $\mathrm{N}$ $\mathrm{NH}_{4}$ concentrations were similar in both layers and throughout tidal periods.

\section{Bacterial carbon metabolism}

Bacterial metabolic rates were highly variable in both sampled layers. BP rates were higher at the surface $\left(0.07\right.$ to $\left.0.36 \mu \mathrm{M} \mathrm{C} \mathrm{h}^{-1} ; \mathrm{CV}=37 \%\right)$, and the highest values were detected during the spring tide period. Near the bottom, no differences between tidal periods

Table 1. Mean \pm SD (in parentheses) of the sampled variables in both layers (surface and bottom [20 m]) during 3 hydrological periods (spring, transition and neap tide). Treatments with the same superscripted letters are not significantly different from each other, according to Tukey's multiple comparison test following ANOVA, at $p<0.05$. DOC, DON, DOP and DOM: dissolved organic carbon, nitrogen, phosphorus and matter, respectively; POC, PON, POP and POM: particulate organic carbon, nitrogen, phosphorus and matter, respectively; DO: dissolved oxygen; Chl a: chlorophyll $a$; BA: bacterial abundance

\begin{tabular}{|c|c|c|c|c|c|c|}
\hline & \multicolumn{3}{|c|}{ - Surface } & \multicolumn{3}{|c|}{ - Bottom - } \\
\hline & Spring & Transition & Neap & Spring & Transition & Neap \\
\hline Temp. $\left({ }^{\circ} \mathrm{C}\right)$ & $23.2^{\mathrm{b}, \mathrm{c}}(0.50)$ & $24.0^{\mathrm{a}, \mathrm{b}}(0.40)$ & $24.1^{\mathrm{a}}(0.52)$ & $22.7^{\mathrm{c}}(0.52)$ & $22.8^{\mathrm{c}}(0.30)$ & $21.7^{\mathrm{d}}(0.63)$ \\
\hline Salinity & $32.1^{\mathrm{b}}(0.80)$ & $30.3^{\mathrm{c}}(1.04)$ & $29.3^{\mathrm{c}}(1.86)$ & $34.3^{\mathrm{a}}(0.20)$ & $34.2^{\mathrm{a}}(0.57)$ & $34.8^{\mathrm{a}}(0.19)$ \\
\hline Density $\left(\sigma_{t}\right)$ & $21.3^{\mathrm{b}}(1.02)$ & $20.1^{\mathrm{c}}(0.87)$ & $19.3^{\mathrm{c}}(0.74)$ & $23.6^{\mathrm{a}}(0.09)$ & $23.5^{\mathrm{a}}(0.52)$ & $24.2^{\mathrm{a}}(0.29)$ \\
\hline $\mathrm{N}-\mathrm{NH}_{4}(\mu \mathrm{M})$ & $3.49^{a}(1.96)$ & $3.64^{\mathrm{a}}(2.47)$ & $4.81^{\mathrm{a}}(2.06)$ & $3.73^{\mathrm{a}}(2.41)$ & $3.01^{\mathrm{a}}(1.15)$ & $3.01^{\mathrm{a}}(3.03)$ \\
\hline $\mathrm{N}-\mathrm{NO}_{2}(\mu \mathrm{M})$ & $0.44^{\mathrm{a}, \mathrm{b}}(0.10)$ & $0.48^{\mathrm{a}}(0.16)$ & $0.55^{\mathrm{a}}(0.11)$ & $0.30^{\mathrm{b}, \mathrm{c}}(0.10)$ & $0.27^{\mathrm{c}}(0.07)$ & $0.27^{\mathrm{c}}(0.06)$ \\
\hline $\mathrm{N}-\mathrm{NO}_{3}(\mu \mathrm{M})$ & $0.55^{\mathrm{b}, \mathrm{c}, \mathrm{d}}(0.11)$ & $0.42^{\mathrm{c}, \mathrm{d}}(0.50)$ & $0.37^{\mathrm{d}}(0.33)$ & $0.86^{\mathrm{b}, \mathrm{c}}(0.09)$ & $1.03^{\mathrm{a}, \mathrm{b}}(0.32)$ & $1.42^{\mathrm{a}}(0.36)$ \\
\hline $\mathrm{P}^{-} \mathrm{PO}_{4}(\mu \mathrm{M})$ & $0.64^{\mathrm{a}}(0.09)$ & $0.56^{\mathrm{a}}(0.20)$ & $0.54^{\mathrm{a}}(0.10)$ & $0.58^{\mathrm{a}}(0.18)$ & $0.46^{\mathrm{a}}(0.11)$ & $0.40^{\mathrm{b}}(0.09)$ \\
\hline $\mathrm{Si}_{-} \mathrm{SiO}_{4}(\mu \mathrm{M})$ & $17.0^{\mathrm{b}}(3.59)$ & $24.4^{\mathrm{a}}(6.52)$ & $28.2^{\mathrm{a}}(6.28)$ & $6.73^{\mathrm{c}}(1.79)$ & $6.22^{\mathrm{c}}(1.48)$ & $5.57^{\mathrm{c}}(0.88)$ \\
\hline DOC $(\mu \mathrm{M})$ & $191^{\mathrm{b}}(29.4)$ & $234^{\mathrm{a}}(34.3)$ & $232^{\mathrm{a}}(38.2)$ & $128^{\mathrm{c}}(24.4)$ & $111^{\mathrm{c}}(15.7)$ & $102^{\mathrm{c}}(6.28)$ \\
\hline DON $(\mu \mathrm{M})$ & $12.4^{\mathrm{a}}(5.25)$ & $16.9^{\mathrm{a}}(5.77)$ & $13.3^{\mathrm{a}}(4.25)$ & $3.71^{\mathrm{b}}(1.63)$ & $2.84^{\mathrm{b}}(1.89)$ & $0.99^{\mathrm{b}}(1.65)$ \\
\hline DOP $(\mu \mathrm{M})$ & $1.24^{\mathrm{a}, \mathrm{b}}(0.56)$ & $1.80^{\mathrm{a}}(0.80)$ & $1.78^{\mathrm{a}}(0.58)$ & $0.52^{\mathrm{C}}(0.10)$ & $0.39^{\mathrm{c}}(0.08)$ & $0.54^{\mathrm{b}, \mathrm{c}}(0.11)$ \\
\hline DOM C:N & $17.4^{\mathrm{c}, \mathrm{d}}(5.82)$ & $15.0^{\mathrm{d}}(3.84)$ & $18.9^{\mathrm{b}, \mathrm{c}, \mathrm{d}}(5.77)$ & $40.7^{\mathrm{a}, \mathrm{b}}(18.1)$ & $44.3^{\mathrm{a}}(26.1)$ & $46.9^{\mathrm{a}, \mathrm{c}}(26.8)$ \\
\hline DOM C:P & $171^{\mathrm{c}}(50.0)$ & $144^{\mathrm{c}}(40.4)$ & $140^{\mathrm{c}}(44.0)$ & $256^{\mathrm{a}, \mathrm{b}}(71.1)$ & $285^{\mathrm{a}}(25.6)$ & $198^{\mathrm{b}, \mathrm{c}}(58.3)$ \\
\hline POC $(\mu \mathrm{M})$ & $117^{\mathrm{a}, \mathrm{b}}(61.1)$ & $163^{a}(108)$ & $165^{a}(87.8)$ & $56.8^{\mathrm{b}}(12.1)$ & $53.6^{\mathrm{b}}(14.9)$ & $39.9^{b}(5.70)$ \\
\hline PON $(\mu \mathrm{M})$ & $17.8^{\mathrm{a}, \mathrm{b}}(8.58)$ & $24.5^{\mathrm{a}}(18.4)$ & $26.3^{\mathrm{a}}(10.9)$ & $6.90^{\mathrm{b}}(3.27)$ & $4.94^{\mathrm{b}}(1.67)$ & $6.92^{\mathrm{b}}(0.89)$ \\
\hline POP $(\mu \mathrm{M})$ & $1.43^{\mathrm{a}, \mathrm{b}}(0.51)$ & $2.10^{\mathrm{a}}(1.06)$ & $2.17^{a}(0.56)$ & $0.59^{\mathrm{b}, \mathrm{c}}(0.08)$ & $0.57^{\mathrm{c}}(0.11)$ & $0.55^{\mathrm{c}}(0.07)$ \\
\hline POM C:N & $6.51^{\mathrm{b}, \mathrm{c}}(0.64)$ & $6.88^{\mathrm{b}, \mathrm{c}}(0.53)$ & $6.06^{\mathrm{b}}(0.65)$ & $9.08^{\mathrm{a}, \mathrm{c}}(2.44)$ & $11.8^{\mathrm{a}}(4.47)$ & $5.76^{\mathrm{b}}(0.30)$ \\
\hline POM C:P & $85.0^{\mathrm{a}, \mathrm{b}}(11.3)$ & $74.1^{\mathrm{a}, \mathrm{b}}(11.7)$ & $74.6^{\mathrm{a}, \mathrm{b}}(29.5)$ & $98.0^{\mathrm{a}}(6.90)$ & $93.6^{a, b}(16.5)$ & $72.4^{\mathrm{b}}(5.33)$ \\
\hline $\mathrm{DO}\left(\mathrm{ml} \mathrm{l}^{-1}\right)$ & $4.46^{\mathrm{a}}(0.50)$ & $4.85^{\mathrm{a}}(0.39)$ & $4.75^{\mathrm{a}}(0.88)$ & $4.18^{\mathrm{a}}(0.17)$ & $4.41^{\mathrm{a}}(0.25)$ & $4.36^{\mathrm{a}}(0.18)$ \\
\hline Chl a $\left(\mu g \mathrm{l}^{-1}\right)$ & $24.7^{\mathrm{b}, \mathrm{c}}(18.7)$ & $53.6^{\mathrm{a}}(40.2)$ & $39.8^{\mathrm{a}, \mathrm{b}}(17.1)$ & $4.35^{\mathrm{c}}(0.52)$ & $5.53^{\mathrm{c}}(0.75)$ & $4.71^{\mathrm{c}}(1.20)$ \\
\hline $\mathrm{BA}\left(10^{5}\right.$ cells ml $\left.\mathrm{ml}^{-1}\right)$ & $7.93^{\mathrm{b}}(1.77)$ & $7.58^{\mathrm{b}}(4.64)$ & $7.89^{b}(2.90)$ & $4.94^{\mathrm{b}}(1.98)$ & $10.1^{\mathrm{a}, \mathrm{b}}(4.28)$ & $16.4^{\mathrm{a}}(7.90)$ \\
\hline
\end{tabular}

Table 2. Mean \pm SD (in parentheses) of microbial rates and ratios in both layers (surface and bottom [20 m]) during 3 hydrological periods (spring, transition and neap tide). Treatments with the same superscripted letters are not significantly different from each other, according to Tukey's multiple comparison test following ANOVA, at p < 0.05. BP: bacterial production; BSP: bacterial specific production; BR: bacterial respiration; BSR: bacterial specific respiration; BCD: bacterial carbon demand; BGE: bacterial growth efficiency; PP: primary production; DOC: dissolved organic carbon

\begin{tabular}{|c|c|c|c|c|c|c|}
\hline & \multicolumn{3}{|c|}{ - Surface } & \multicolumn{3}{|c|}{ - Bottom - } \\
\hline & Spring & Transition & Neap & Spring & Transition & Neap \\
\hline $\mathrm{BP}\left(\mu \mathrm{M} \mathrm{C} \mathrm{h}^{-1}\right)$ & $0.26^{\mathrm{a}}(0.08)$ & $0.17^{\mathrm{b}}(0.06)$ & $0.17^{b}(0.05)$ & $0.08^{\mathrm{C}}(0.03)$ & $0.04^{\mathrm{c}}(0.01)$ & $0.03^{\mathrm{c}}(0.01)$ \\
\hline BSP $\left(10^{-9} \mu \mathrm{mol} \mathrm{C} \mathrm{cell}{ }^{-1} \mathrm{~h}^{-1}\right)$ & $0.35^{\mathrm{a}}(0.16)$ & $0.28^{\mathrm{a}}(0.16)$ & $0.24^{\mathrm{a}}(0.11)$ & $0.20^{\mathrm{a}, \mathrm{b}}(0.11)$ & $0.07^{\mathrm{b}, \mathrm{c}}(0.08)$ & $0.02^{\mathrm{c}}(0.01)$ \\
\hline $\mathrm{BR}\left(\mu \mathrm{M} \mathrm{C} \mathrm{h}^{-1}\right)$ & $0.22^{\mathrm{a}}(0.26)$ & $0.29^{\mathrm{a}}(0.22)$ & $0.25^{\mathrm{a}}(0.19)$ & $0.26^{\mathrm{a}}(0.20)$ & $0.21^{\mathrm{a}}(0.16)$ & $0.24^{\mathrm{a}}(0.14)$ \\
\hline $\operatorname{BSR}\left(10^{-9} \mu \mathrm{mol} \mathrm{C}\right.$ cell $\left.^{-1} \mathrm{~h}^{-1}\right)$ & $0.28^{\mathrm{a}}(0.31)$ & $0.38^{\mathrm{a}}(0.24)$ & $0.34^{\mathrm{a}}(0.29)$ & $0.63^{\mathrm{a}}(0.56)$ & $0.31^{\mathrm{a}}(0.26)$ & $0.13^{\mathrm{a}}(0.06)$ \\
\hline $\mathrm{BCD}\left(\mu \mathrm{M} \mathrm{C} \mathrm{h}^{-1}\right)$ & $0.42^{\mathrm{a}}(0.21)$ & $0.46^{\mathrm{a}}(0.24)$ & $0.37^{\mathrm{a}, \mathrm{b}}(0.20)$ & $0.31^{\mathrm{a}, \mathrm{b}}(0.20)$ & $0.20^{\mathrm{a}, \mathrm{b}}(0.16)$ & $0.14^{\mathrm{b}}(0.15)$ \\
\hline BGE & $0.63^{\mathrm{a}}(0.28)$ & $0.44^{\mathrm{a}, \mathrm{b}}(0.17)$ & $0.49^{\mathrm{a}, \mathrm{b}}(0.23)$ & $0.31^{\mathrm{a}, \mathrm{b}}(0.24)$ & $0.24^{\mathrm{b}}(0.17)$ & $0.14^{\mathrm{b}}(0.07)$ \\
\hline $\mathrm{PP}\left(\mu \mathrm{M} \mathrm{C} \mathrm{h}^{-1}\right)$ & $8.78^{\mathrm{a}}(8.26)$ & $13.1^{\mathrm{a}}(6.52)$ & $20.3^{\mathrm{a}}(19.6)$ & $0.20^{\mathrm{a}}(0.12)$ & $0.21^{\mathrm{a}}(0.14)$ & $0.38^{\mathrm{a}}(0.37)$ \\
\hline $\mathrm{BP}+\mathrm{PP}\left(\mu \mathrm{M} \mathrm{C} \mathrm{h}^{-1}\right)$ & $9.08^{\mathrm{a}}(8.29)$ & $13.3^{\mathrm{a}}(6.51)$ & $20.5^{\mathrm{a}}(19.6)$ & $0.30^{\mathrm{a}}(0.12)$ & $0.26^{\mathrm{a}}(0.14)$ & $0.42^{\mathrm{a}}(0.38)$ \\
\hline BP:PP & $0.07^{\mathrm{a}}(0.08)$ & $0.02^{\mathrm{a}}(0.01)$ & $0.02^{\mathrm{a}}(0.01)$ & $0.81^{\mathrm{a}}(0.82)$ & $0.52^{\mathrm{a}}(0.70)$ & $0.19^{\mathrm{a}}(0.15)$ \\
\hline BCD:PP & $0.10^{\mathrm{a}}(0.11)$ & $0.04^{\mathrm{a}}(0.02)$ & $0.02^{\mathrm{a}}(0.01)$ & $2.12^{\mathrm{a}}(2.61)$ & $1.05^{\mathrm{a}}(0.48)$ & $1.06^{\mathrm{a}}(1.89)$ \\
\hline DOC:BCD (d) & $22.5^{\mathrm{b}}(9.55)$ & $28.8^{\mathrm{b}}(23.1)$ & $36.8^{\mathrm{b}}(24.9)$ & $22.9^{\mathrm{b}}(13.6)$ & $46.1^{\mathrm{b}}(43.6)$ & $70.5^{\mathrm{a}}(49.6)$ \\
\hline
\end{tabular}



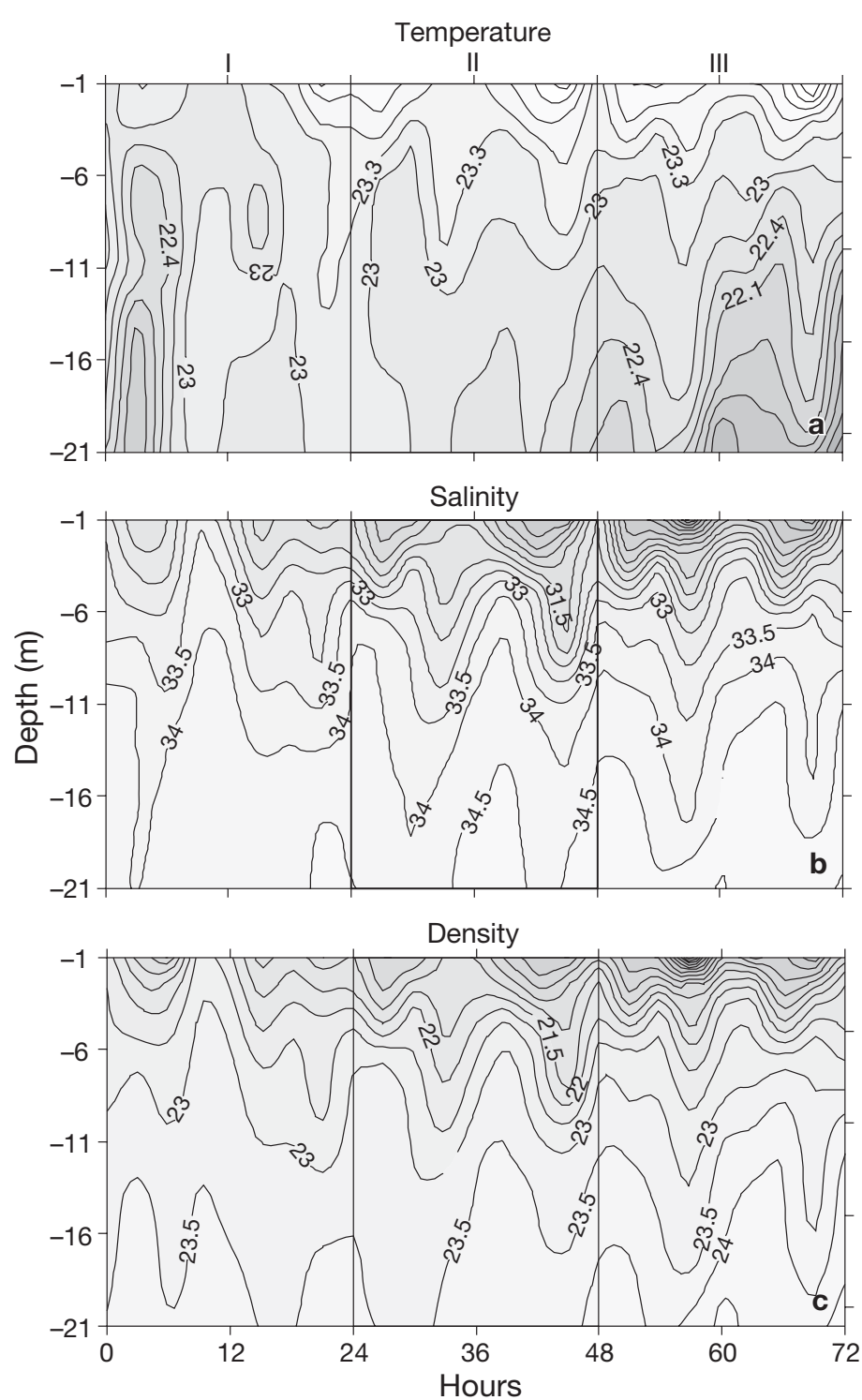

Fig. 4. (a) Isotherms $\left({ }^{\circ} \mathrm{C}\right)$, (b) isohalines and (c) isopycnals $\left(\sigma_{\mathrm{t}}\right)$ during (I) spring tide, (II) transition and (III) neap tide

were observed: 0.02 to $0.11 \mu \mathrm{M} \mathrm{C} \mathrm{h}{ }^{-1} ; \mathrm{CV}=51 \%$ (Table 2, Fig. 6b). BSP rates during spring tide overlapped in both layers: $0.16 \times 10^{-9}$ to $0.60 \times 10^{-9} \mu \mathrm{mol} \mathrm{C}$ cell $^{-1} \mathrm{~h}^{-1}$ at the surface and $0.04 \times 10^{-9}$ to $0.34 \times 10^{-9}$ $\mu \mathrm{mol} \mathrm{C}$ cell $^{-1} \mathrm{~h}^{-1}$ near the bottom. During the transition and neap tide periods, BSP decreased towards the bottom $\left(0.01 \times 10^{-9}\right.$ to $0.06 \times 10^{-9} \mu \mathrm{mol} \mathrm{C}$ cell $\left.^{-1} \mathrm{~h}^{-1}\right)$, being significantly lower than at the surface $\left(0.08 \times 10^{-9}\right.$ to $0.57 \times 10^{-9} \mu \mathrm{mol} \mathrm{C}$ cell $\left.^{-1} \mathrm{~h}^{-1}\right)$. High variation in BSP was observed in both layers: $\mathrm{CV}_{\text {surface }}=49 \%$ and $\mathrm{CV}_{\text {bottom }}=$ $111 \%$ (Table 2, Fig. 6c).

$\mathrm{BR}$ rates were more variable than $\mathrm{BP}$ rates $(0.03$ to $\left.0.71 \mu \mathrm{M} \mathrm{C} \mathrm{h}^{-1} ; \mathrm{CV}_{\text {surface }}=84 \%, \mathrm{CV}_{\text {bottom }}=68 \%\right)$. No significant differences between tidal periods or layers

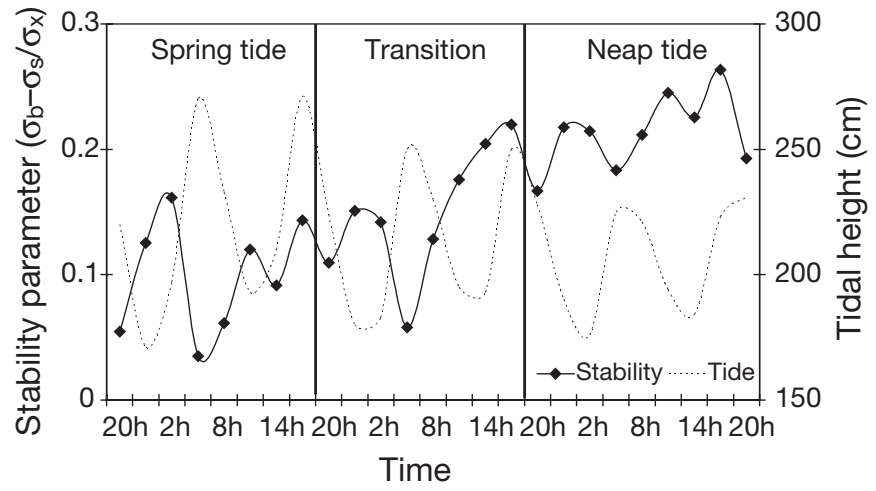

Fig. 5. Water-column stability: $\left[\left(\sigma_{\mathrm{b}}-\sigma_{\mathrm{s}}\right) / \sigma_{\mathrm{x}}\right]$ during spring tide, transition and neap tide

were observed (Table 2, Fig. 6d). BSR rates, also highly variable $\left(\mathrm{CV}_{\text {surface }}=78 \%, \mathrm{CV}_{\text {bottom }}=107 \%\right)$, ranged from $0.03 \times 10^{-9}$ to $0.72 \times 10^{-9} \mu \mathrm{mol} \mathrm{C}$ cell ${ }^{-1} \mathrm{~h}^{-1}$ in both layers. No significant differences between tidal periods or layers were observed (Table 2, Fig. 6e).

$\mathrm{BCD}$ was also equivalent between layers and periods: surface $=0.04$ to $0.76 \mu \mathrm{M} \mathrm{C} \mathrm{h}^{-1} ; \mathrm{CV}=50 \%$; bottom $=0.13$ to $0.85 \mu \mathrm{M} \mathrm{C} \mathrm{h}^{-1} ; \mathrm{CV}=83 \%$ (Table 2, Fig. 6f). BGE was highly variable between layers and periods (surface: 15 to $93 \%$; CV $=45 \%$; bottom: 6 to $80 \% ; \mathrm{CV}=77 \%)$. However, the average BGE at the surface was higher than that near the bottom: 52 and $23 \%$, respectively (Table 2 , Fig. $6 g$ ).

$\mathrm{PP}$ rates were also highly variable in both layers (surface: 1.9 to $48.5 \mu \mathrm{M} \mathrm{C} \mathrm{h}^{-1}$; $\mathrm{CV}=90 \%$; bottom: 0.04 to $0.93 \mu \mathrm{M} \mathrm{C} \mathrm{h}^{-1} ; \mathrm{CV}=88 \%$ ). The highest values in both layers were detected at noon (incubation period: 12:00 to $15: 00 \mathrm{~h})$ and the lowest at the beginning $(05: 00$ to 08:00 h) and at the end of the day (14:00 to $17: 00 \mathrm{~h})$. No significant differences between tidal periods or layers were observed, despite the high PP values observed at the surface (Table 2, Fig. 6h).

Total POC production (BP + PP) ranged from 2.3 to $48.7 \mu \mathrm{M} \mathrm{C} \mathrm{h}^{-1}$ at the surface ( $\left.\mathrm{CV}=88 \%\right)$ and 0.1 to $1.0 \mu \mathrm{M} \mathrm{C} \mathrm{h}^{-1}$ near the bottom ( $\left.\mathrm{CV}=71 \%\right)$. BP ranged from 0.4 to $19 \%$ of PP at the surface and 5.0 to $52 \%$ near the bottom, with 2 peaks of 157 and $200 \%$ at stations sampled at 05:00 $\mathrm{h}$ in the spring and transition periods. BCD ranged from 2.0 to $26 \%$ of $\mathrm{PP}$ at the surface and 5.0 to $590 \%$ near the bottom. The DOC turnover through bacterioplankton consumption ranged from 9.3 to $50.7 \mathrm{~d}$ during spring tide and 8.2 to $134.6 \mathrm{~d}$ during transition and neap tide periods in both layers. Significant differences were found only for DOC turnover during the neap tide period near the bottom (Table 2).

The multiple regression models performed for bacterial metabolic rates with selected variables showed that BSP and BGE variations were directly dependent 

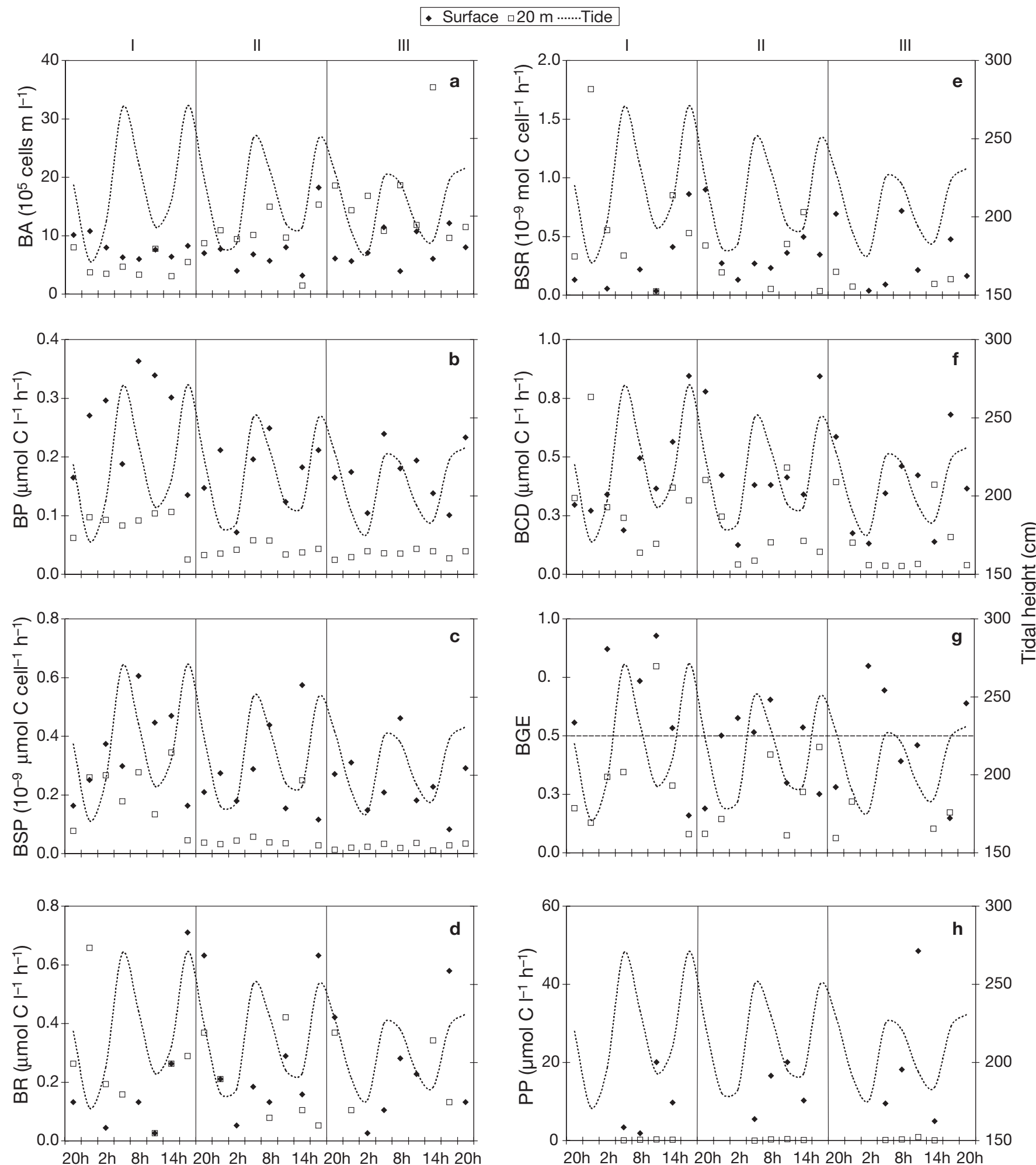

Time

Fig. 6. (a) Bacterial abundance (BA), (b) bacterial production (BP), (c) bacterial specific production (BSP), (d) bacterial respiration (BR), (e) bacterial specific respiration (BSR), (f) bacterial carbon demand (BCD), (g) bacterial growth efficiency (BGE) and (h) primary production (PP) at the entrance to Guanabara Bay during (I) spring tide, (II) transition and (III) neap tide. Dashed lines indicate tidal height 
Table 3. Multiple regression models: $\mathrm{R}^{2}, \beta$ and partial $\mathrm{r}$ values (in parentheses below $\beta$ values) for bacterial metabolic rate variations with selected variables. Significant differences at: ${ }^{*} p<0.05,{ }^{* *} p<0.01$, and ${ }^{* * *} p<0.001$. Abbreviations see Tables $1 \& 2$

\begin{tabular}{|c|c|c|c|c|c|c|c|c|c|c|c|c|}
\hline & \multicolumn{6}{|c|}{ - Surface } & \multirow[b]{2}{*}{ BP } & \multirow[b]{2}{*}{ BSP } & $-20 \mathrm{r}$ & \multirow{2}{*}{$\mathrm{BSR}$} & \multirow[b]{2}{*}{$\mathrm{BCD}$} & \multirow[b]{2}{*}{ BGE } \\
\hline & BP & BSP & BR & BSR & $\mathrm{BCD}$ & BGE & & & $\mathrm{BR}$ & & & \\
\hline $\mathrm{R}^{2}$ & $0.57^{* *}$ & $0.62^{* * *}$ & $0.68^{* *}$ & $0.74^{* *}$ & $0.60^{* *}$ & $0.77^{* *}$ & $0.43^{* *}$ & $0.44^{*}$ & $0.40^{*}$ & $0.60^{*}$ & $0.75^{*}$ & $0.62^{*}$ \\
\hline$\beta\left(\mathrm{N}-\mathrm{NH}_{4}\right)$ & & $\begin{array}{c}0.58^{* *} \\
(0.64)\end{array}$ & $\begin{array}{l}0.62^{*} \\
(0.59)\end{array}$ & & & $\begin{array}{l}-0.50^{*} \\
(-0.52)\end{array}$ & & & & & & \\
\hline$\beta\left(\mathrm{N}-\mathrm{NO}_{3}\right)$ & & & & & & & & & & & $\begin{array}{l}-0.71^{*} \\
(-0.65)\end{array}$ & $\begin{array}{l}0.61^{*} \\
(0.57)\end{array}$ \\
\hline$\beta\left(\mathrm{P}-\mathrm{PO}_{4}\right)$ & & & $\begin{array}{c}-0.51^{* *} \\
(-0.59)\end{array}$ & & & $\begin{array}{l}0.45^{* *} \\
(0.61)\end{array}$ & & $\begin{array}{l}0.59^{*} \\
(0.61)\end{array}$ & & $\begin{array}{l}0.88^{* *} \\
(0.77)\end{array}$ & & \\
\hline$\beta(\mathrm{DOC})$ & $\begin{array}{l}-0.81^{*} \\
(-0.50)\end{array}$ & $\begin{array}{c}-1.00^{* * *} \\
(-0.71)\end{array}$ & & & & & $\begin{array}{l}0.61^{* *} \\
(0.63)\end{array}$ & & & & & \\
\hline$\beta(\mathrm{DOM} C: \mathrm{N})$ & $\begin{array}{l}-0.48^{*} \\
(-0.48)\end{array}$ & $\begin{array}{c}-0.50^{* *} \\
(-0.59)\end{array}$ & $\begin{array}{l}-0.41^{*} \\
(-0.49)\end{array}$ & & & & & & & & & $\begin{array}{l}-0.67^{*} \\
(-0.61)\end{array}$ \\
\hline$\beta$ (DOM C:P) & & & $\begin{array}{l}0.64^{*} \\
(0.54)\end{array}$ & & & $\begin{array}{c}-0.68^{* *} \\
(-0.63)\end{array}$ & & & $\begin{array}{l}0.64^{* *} \\
(0.62)\end{array}$ & & & $\begin{array}{c}-0.78^{* *} \\
(-0.71)\end{array}$ \\
\hline$\beta(\mathrm{DO})$ & $\begin{array}{l}0.73^{*} \\
(0.57)\end{array}$ & & & $\begin{array}{c}-0.75^{* *} \\
(-0.65)\end{array}$ & & & & & & & & \\
\hline$\beta$ (temp.) & $\begin{array}{l}-0.77^{*} \\
(-0.48)\end{array}$ & & & $\begin{array}{c}1.61^{* * *} \\
(0.78)\end{array}$ & $\begin{array}{l}1.00^{*} \\
(0.53)\end{array}$ & $\begin{array}{c}-1.09^{* *} \\
(-0.67)\end{array}$ & & & & & & \\
\hline$\beta$ (salinity) & & & $\begin{array}{l}1.03^{* *} \\
(0.63)\end{array}$ & $\begin{array}{l}0.73^{*} \\
(0.57)\end{array}$ & $\begin{array}{l}0.75^{*} \\
(0.49)\end{array}$ & $\begin{array}{c}-1.16^{* * *} \\
(-0.73)\end{array}$ & & & & & & \\
\hline$\beta(\operatorname{chl} a)$ & & & $\begin{array}{c}1.02^{* * *} \\
(0.71)\end{array}$ & $\begin{array}{l}0.78^{*} \\
(0.60)\end{array}$ & $\begin{array}{l}0.70^{*} \\
(0.53)\end{array}$ & $\begin{array}{c}-1.06^{* *} \\
(-0.70)\end{array}$ & & & & & & \\
\hline
\end{tabular}

on nutrients ( $\mathrm{N}-\mathrm{NH}_{4}$ or $\left.\mathrm{P}-\mathrm{PO}_{4}\right)$ and inversely dependent on DOM C:N or C:P ratios. Temperature had a positive influence on BSR and was inversely correlated to BGE (Table 3).

\section{DISCUSSION}

The present study shows that bacterial metabolic rates were highly variable due to tidal oscillation over a short-term temporal survey at the entrance to Guanabara Bay, but that the magnitude of carbon flow through bacterioplankton differed systematically between depths. The dominance of allochthonous DOM, along with variations in temperature, were the main controlling factors of bacterial carbon metabolism at that area.

The higher water-column stability at transition and neap tide periods suggests the establishment of gravitational circulation: outflow at the surface and inflow near the bottom, as already observed in a simultaneous circulation study performed in the same area (Bergamo 2006). The observed decrease in salinity and increase in temperature and chl $a$ at the surface during those periods indicate the influence of the inner bay waters, where those variables have values that are typically higher than in the adjacent ocean (Valentin et al. 1999a). Likewise, the decrease in temperature and increase in $\mathrm{N}-\mathrm{NO}_{3}$ concentrations near the bottom demonstrate the influence of the coastal ocean (Kjerfve et al. 1997). During the spring tide period, stronger water-column mixing resulted in an increased homogeneity in the dissolved and particulate material, which did not vary significantly over depth, and thus no clear influence of the adjacent areas (inner bay and coastal ocean) was observed. This variation in circulation dynamics did not affect the patterns in $\mathrm{POM}$ and DOM elemental composition or N-NH 4 and $\mathrm{P}_{-} \mathrm{PO}_{4}$ contents. The observed POM C:N and C:P ratios, similar in both layers and to phytoplankton elemental composition (Goldman 1986), suggest the dominance of autochthonous POM throughout the water column at the entrance to the bay. This same pattern was observed using a combination of elemental and isotopic composition analyses of POM in sediment samples throughout the main channel of the bay (Carreira et al. 2002) and in the adjacent coastal ocean (Matsuura \& Wada 1994). In contrast, allochthonous POM, derived from riverine or terrestrial sources, dominates the sediment of inner bay areas (Carreira et al. 2002). The high DOM C:N and C:P ratios observed at the entrance to the bay, especially towards the bottom, indicate the predominance of allochthonous DOM in this area (Findlay et al. 1991). Thus, despite the high PP rates at the surface, the contribution of phytoplankton to the DOM pool, through excretion for example 
(Baines \& Pace 1991), was probably lower than that from terrestrial inputs.

The allochthonous DOM, generally rich in refractory components such as humic substances, is not as easily decomposed by heterotrophic bacteria as autochthonous algal DOM exudates (Moran \& Hodson 1989, Obernosterer \& Herndl 1995). The long apparent DOC turnover times as a result of bacterial consumption, especially during transition and neap tide periods, indicates that only a small fraction of the DOM pool was consumed during the time frame of transit in the system, probably due to its chemical nature and low DON and DOP contents. Moreover, DOC concentrations and DOM C:N ratios explained, respectively, 50 and $34 \%$ of surface BSP variation. The inverse correlation between those variables and BSP indicates that, although the DOC pool is large, the quality of DOM may be limiting bacterial growth. Near the bottom, the highest BSP rates were observed at the beginning of the study period, when DOC concentrations were higher, but $\mathrm{C}: \mathrm{N}$ and $\mathrm{C}: \mathrm{P}$ ratios were lowest. Bacterioplankton can balance the high DOM C:N or C:P ratios through inorganic N or P uptake (Kirchman 1994). The concentrations of $\mathrm{N}-\mathrm{NH}_{4}$ at the surface and $\mathrm{P}-\mathrm{PO}_{4}$ near the bottom explained, respectively, 41 and $37 \%$ of BSP variation. The direct correlation between those nutrients and bacterial growth suggests that bacteria may be meeting their organic $\mathrm{N}$ and $\mathrm{P}$ requirements through inorganic nutrient uptake. The importance of DOM supply and quality in regulating BGE in tropical and temperate estuarine systems has already been pointed out (e.g. del Giorgio \& Cole 1998, Ram et al. 2003).

Besides DOM elemental composition, temperature was also an important factor regulating BGE at the entrance to Guanabara Bay. High temperatures usually accelerate respiration rates, and inverse correlations between BGE and temperature have already been observed in marine and coastal systems (e.g. Rivkin \& Legendre 2001, Apple et al. 2006). Despite the small temperature range observed at the surface during the present study $\left(23\right.$ to $25^{\circ} \mathrm{C}$ ), higher temperatures led to higher BSR rates and to lower BGE.

The same range of variability in BP and BR observed here, over a short temporal scale, was found in other estuarine systems over larger temporal and spatial scales (e.g. Roland \& Cole 1999, Maranger et al. 2005, Apple et al. 2006). Moreover, the BGE range observed in the present study was similar to that found across different aquatic systems (e.g. del Giorgio \& Cole 1998, Rivkin \& Legendre 2001). Contrarily to the better established ${ }^{3} \mathrm{H}$-leucine-based methods for BP assessment, BR estimates present several methodological difficulties. These include the long-term incubations (24 h at least) and the isolation from other plankton compo- nents and, hence, sources of organic matter and recycled nutrients (del Giorgio \& Cole 2000). In the present study, the low number of replicates constituted an additional source of uncertainty to BR measurements, compromising BGE evaluation. However, it is also possible that the observed BGE variability owes, not only to these shortcomings, but to the hydrodynamic complexity of the entrance to Guanabara Bay, and may also occur over short-term temporal scales within other complex estuarine systems. Most BGE studies to date have assessed large temporal scales, and those performed in estuarine systems have not taken into account variations due to tidal oscillations. Therefore, more studies assessing small temporal scales are needed in order to verify to what extent the variations observed between systems may reflect temporal sampling artefacts. If this is so, the use of a single BGE in those systems could be misleading (either over- or underestimated). However, if BGE values were relatively constant, even at small temporal scales, the sources of such distinct cross-system patterns should be more thoroughly investigated.

In spite of the high variability in bacterial metabolic rates, the magnitude of carbon flow through bacterioplankton at the entrance to Guanabara Bay differed between layers. Similar BSR rates in surface and bottom layers and lower BSP rates near the bottom indicate that bacterioplankton respiration was relatively uniform throughout the water column, but biomass production was higher at the surface. Therefore, while $\mathrm{BP}$ was equivalent to respiration at that layer $(\mathrm{BGE}=$ $52 \%$ ), bacterial DOM remineralisation was higher than POC production near the bottom (BGE $=23 \%$ ). Besides DOM composition, nutrient availability and temperature variations, which influence the bacterial energetic budget (Williams 2000), other factors not investigated in the present study can also affect the proportions of more or less active bacterial cells and, hence, BGE. This includes trophic interactions, mainly selective grazing or viral infection on larger, more active cells, and the phylogenetic composition of the bacterial community, as different taxonomic groups can present distinct patterns of organic matter and nutrient utilization under the same environmental conditions (del Giorgio \& Cole 2000). The interactions between bacterioplankton metabolism and phytoplankton production directly influenced the carbon budget in both layers. At the surface, total POC production was mainly due to phytoplankton, and the low $\mathrm{BCD}: \mathrm{PP}$ ratios suggest that a small fraction of this autotrophic production was channelled, via DOC release, to bacterioplankton (Smith et al. 1995). The high PP:BR ratio (>50) indicates that this layer was net autotrophic, as total community respiration rates at that area of the bay were mainly due to bacterioplank- 
ton (Guenther 2006). The photic layer at the entrance to Guanabara Bay was only $5 \mathrm{~m}$ deep, and no light reached the bottom $\left(0.06 \mu \mathrm{E} \mathrm{m} \mathrm{m}^{-2} \mathrm{~s}^{-1}\right.$ in either day or night periods). The resulting low PP at that layer was similar to BR, thus suggesting a tendency to heterotrophy.

The present study shows that the circulation dynamics at Guanabara Bay, driven by forces related to tidal amplitude, resulted in variations in nutrient and organic matter concentrations. These, in turn, affected the magnitude of carbon flow through the bacterioplankton in the surface and bottom layers and can interfere directly with the carbon cycling within the water column, as well as between the adjacent ocean and the inner bay. The transfer of the autochthonous POC and DOC produced at the surface to the bottom will depend on water-column mixing, more frequent during the spring tide period, while the carbon exchange between the adjacent areas in both layers will depend on gravitational circulation, established during the neap tide period. The high variability in bacterial metabolic rates over this short-term survey highlights the importance of high-resolution studies for understanding the carbon cycle of complex hydrodynamic estuarine systems.

Acknowledgements. The authors thank Petrobras and the RV 'Astrogaroupa' crew for field support, several undergraduate students and technicians for field and laboratory support, L. B. Miranda and A. L. Bergamo for helpful sugestions on physical data analyses, and P. A. del Giorgio, D. Astúa and 3 anonymous referees for suggestions that substantially improved the quality of the manuscript. Field work and analyses were supported by grants from the National Research Council (CNPq-3306.188/2004-0) and the Rio de Janeiro State Research Foundation (FAPERJ-E-26/151.949/2004). M.G. was supported by a doctoral fellowship from CNPq (141873/2003-5), and is currently supported by a post-doctoral fellowship from CNPq/FACEPE (BFP-0023-1.08/06).

\section{LITERATURE CITED}

Amador ES (1997) Baía de Guanabara e ecossistemas periféricos: homem e natureza. Reproarte, Rio de Janeiro

Aminot A, Chaussepied M (1983) Manuel des analyses chimiques en milieu marin. Centre National pour l'Exploitation des Oceans, Brest

Apple JK, del Giorgio PA, Kemp WM (2006) Temperature regulation of bacterial production, respiration, and growth efficiency in a temperate salt-marsh estuary. Aquat Microb Ecol 43:243-254

Baines S, Pace M (1991) The production of dissolved organic matter by phytoplankton and its importance to bacteria: patterns across marine and freshwater systems. Limnol Oceanogr 36:1078-1090

Bergamo AL (2006) Características hidrográficas, da circulação e dos transportes de volume e sal na Baía de Guanabara (RJ): variações sazonais e moduladas pela maré. $\mathrm{PhD}$ thesis, University of São Paulo
Biddanda B, Opsahl S, Benner R (1994) Plankton respiration and carbon flux through bacterioplankton on the Louisiana Shelf. Limnol Oceanogr 39:1259-1275

Carreira RS, Wagener ALR, Readman JW, Fileman TW, Macko SA, Veiga A (2002) Changes in the sedimentary organic carbon pool of a fertilized tropical estuary, Guanabara Bay, Brazil: an elemental, isotopic and molecular marker approach. Mar Chem 79:207-227

del Giorgio PA, Cole JJ (1998) Bacterial growth efficiency in natural aquatic systems. Annu Rev Ecol Syst 29:503-541

del Giorgio PA, Cole JJ (2000) Bacterial energetics and growth efficiency. In: Kirchman DL (ed) Microbial ecology of the oceans. Wiley-Liss, New York, p 289-326

del Giorgio PA, Bird DF, Prairie YT, Planas D (1996) Flow cytometric determination of bacterial abundance in lake plankton with the green nucleic acid stain SYTO 13. Limnol Oceanogr 41:783-789

del Giorgio PA, Cole JJ, Cimbleris A (1997) Respiration rates in bacteria exceed phytoplankton production in unproductive aquatic systems. Nature 385:148-150

del Giorgio PA, Pace ML, Fischer D (2006) Relationship of bacterial growth efficiency to spatial variation in bacterial activity in the Hudson River. Aquat Microb Ecol 45:55-67

Ducklow H (2000) Bacterial production and biomass in the oceans. In: Kirchman DL (ed) Microbial ecology of the oceans. Wiley-Liss, New York, p 85-120

Dyer KR (1997) Estuaries: a physical introduction. John Wiley \& Sons, Chichester

Findlay S, Pace ML, Lints D, Cole JJ, Caraco NF, Peierls B (1991) Weak coupling of bacterial and algal production in a heterotrophic ecosystem: the Hudson river estuary. Limnol Oceanogr 36:268-278

Goldman JC (1986) On phytoplankton growth rates and particulate C-N-P ratios at low light. Limnol Oceanogr 31: 1358-1363

Gonzalez AM, Paranhos R, Andrade L, Valentin JL (2000) Bacterial production in Guanabara Bay (Rio de Janeiro, Brazil) evaluated by ${ }^{3} \mathrm{H}$-leucine incorporation. Braz Arch Biol Technol 43:493-500

Grasshoff KA, Ehrhardt M, Kremling K (1983) Methods for seawater analysis. Verlag Chemie, Weinheim

Guenther M (2006) Efeito de fontes distintas de eutrofização, antrópica e natural, na estrutura de tamanho do fitoplâncton e na relação entre a produção primária e bacteriana: estudos na Baía de Guanabara e na região de ressurgência de Cabo Frio, RJ. PhD thesis, University of São Paulo

Jahnke RA, Craven DB (1995) Quantifying the role of heterotrophic bacteria in the carbon cycle: a need for respiration rate measurements. Limnol Oceanogr 40:436-441

JICA (Japan International Cooperation Agency) (1994) The study on recuperation of the Guanabara bay ecosystem. Supporting report, JICA, Tokyo

Kirchman DL (1994) The uptake of inorganic nutrients by heterotrophic bacteria. Microb Ecol 28:255-271

Kjerfve B, Ribeiro CHA, Dias GTM, Filippo AM, Quaresma VD (1997) Oceanographic characteristics of an impacted coastal bay: Baía de Guanabara, Rio de Janeiro, Brazil. Cont Shelf Res 17:1609-1643

Lebaron P, Troussellier M, Got P (1994) Accuracy and precision of epifluorescence microscopy counts for direct estimates of bacterial numbers. J Microbiol Methods 19: $89-94$

Lemée R, Rochelle-Newall E, Van Wambeke F, Pizay MD, Rinaldi P, Gattuso JP (2002) Seasonal variation of bacterial production, respiration and growth efficiency in the open NW Mediterranean Sea. Aquat Microb Ecol 29:227-237 
Maranger RJ, Pace ML, del Giorgio PA, Caraco NF, Cole JJ (2005) Longitudinal spatial patterns of bacterial production and respiration in a large river-estuary: implications for ecosystem carbon consumption. Ecosystems (NY, Print) 8:318-330

Matsuura Y, Wada E (1994) Carbon and nitrogen stable isotope ratios in marine organic matters of the coastal ecosystem in Ubatuba, southern Brazil. Cienc Cult 46:141-146

Mayr LM, Tenembaum DR, Villac MC, Paranhos R, Nogueira CR, Bonecker SLC, Bonecker ACT (1989) Hydrobiological characterization of Guanabara Bay. In: Magoon O, Neves C (eds) Coastlines of Brazil. American Society of Civil Engineers, New York, p 124-138

McLusky DS (1989) The estuarine ecosystem. Blackwell, Glasgow

Moran MA, Hodson RE (1989) Bacterial secondary production on vascular plant detritus - relationships to detritus composition and degradation rate. Appl Environ Microbiol $55: 2178-2189$

> Obernosterer I, Herndl GJ (1995) Phytoplankton extracellular release and bacterial growth-dependence on the inorganic N-P ratio. Mar Ecol Prog Ser 116:247-257

Paranhos R, Pereira AP, Mayr LM (1998) Diel variability of water quality in a tropical polluted bay. Environ Monit Assess 50:131-141

Paranhos R, Andrade L, Mendonça-Hagler LC, Pfeiffer WC (2001) Coupling bacterial abundance with production in a polluted tropical coastal bay. In: Faria BM, Farjalla VF, Esteves FA (eds) Aquatic microbial ecology in Brazil. PPGE-UFRJ, Rio de Janeiro, p 117-132

Parsons TR, Maita Y, Lalli CM (1984) A manual of chemical and biological methods for seawater analysis. Pergamon Press, Oxford

Ram ASP, Nair S, Chandramohan D (2003) Bacterial growth efficiency in the tropical estuarine and coastal waters of

Editorial responsibility: Paul del Giorgio,

Montreal, Quebec, Canada
Goa, southwest coast of India. Microb Ecol 45:88-96

Reinthaler T, Herndl GJ (2005) Seasonal dynamics of bacterial growth efficiencies in relation to phytoplankton in the southern North Sea. Aquat Microb Ecol 39:7-16

Rivkin RB, Legendre L (2001) Biogenic carbon cycling in the upper ocean: effects of microbial respiration. Science 291:2398-2400

Roland F, Cole JJ (1999) Regulation of bacterial growth efficiency in a large turbid estuary. Aquat Microb Ecol 20:31-38

Simon M, Azam F (1989) Protein-content and protein-synthesis rates of planktonic marine-bacteria. Mar Ecol Prog Ser 51:201-213

Smith D, Azam F (1992) A simple, economical method for measuring bacterial protein synthesis rates in seawater using ${ }^{3}$ H-leucine. Mar Microb Food Webs 6:107-114

Smith DC, Steward GF, Long RA, Azam F (1995) Bacterial mediation of carbon fluxes during a diatom bloom in a mesocosm. Deep-Sea Res II 42:75-97

Steemann-Nielsen E (1952) The use of radio-active carbon $\left({ }^{14} \mathrm{C}\right)$ for measuring organic production in the sea. J Cons Int Explor Mer 18:117-140

Valentin JL, Tenenbaum DR, Bonecker ACT, Bonecker SLC, Nogueira CR, Paranhos R, Villac MC (1999a) Caractéristiques hydrobiologiques de la baie de Guanabara (Rio de Janeiro, Brésil). J Rech Ocean 24:33-41

Valentin JL, Tenenbaum DR, Bonecker ACT, Bonecker SLC, Nogueira CR, Villac MC (1999b) O sistema planctônico da Baía de Guanabara: Síntese do conhecimento. In: Silva S, Lavrado H (eds) Ecologia dos Ambientes Costeiros do Estado do Rio de Janeiro. PPGE-UFRJ, Rio de Janeiro, p 35-59

Williams PJleB (2000) Heterotrophic bacteria and the dynamics of dissolved organic material. In: Kirchman DL (ed) Microbial ecology of the oceans. Wiley-Liss, New York, p 153-200

Submitted: November 11, 2006; Accepted: September 24, 2007 Proofs received from author(s): December 14, 2007 